\title{
Physiochemical characteristics of Platycodon grandiflorum flower ethanolic extracts
}

\author{
Jae Ran Kang, Min Jung Kang, A Ro Cho, Jung Hye Shin* \\ Namhae Garlic Research Institute, Namhae 52430, Korea
}

\section{도라지(Platycodon grandiflorum) 꽃 주정 추출물의 이화학적 특성}

\author{
강재란 · 강민정 · 조아로 · 신정혜* \\ (재) 남해마늘연구소
}

\begin{abstract}
The goal of this study was to investigate the physicochemical characteristics of Platycodon grandiflorum flower extracts obtained with different ratios of edible ethanol containing water solutions $(10 \%, 30 \%$ and $60 \%$ ethanol). The redness and $\mathrm{pH}$ values of the extracts increased with increasing ethanol content, whereas the acidity decreased. The total phenol, total flavonoid, and total anthocyanin contents were in the ranges of 105.94-113.79 $\mu \mathrm{g} / \mathrm{mL}, 11.97-27.13$ $\mu \mathrm{g} / \mathrm{mL}$, and 0.01-0.13 $\mu \mathrm{g} / \mathrm{mL}$, respectively, all of which were significantly high and decreased in the order of $60 \%$ $>30 \%>10 \%$ ethanol. The antioxidant activity and cholesterol adsorption activity generally followed the order of $60 \%>10 \%>30 \%$ ethanol, and the a-glucosidase inhibitory activity was significantly higher in the $10 \%$ ethanol extract, followed by the $30 \%>60 \%$ ethanol extract. However, there was no identifiable significant difference in the xanthine oxidase inhibitory activities obtained using the different ethanol addition ratios when the sample concentration was $5 \mu \mathrm{g} / \mathrm{mL}$. The physiological activities of the ethanol extracts of $P$. grandiflorum flowers are estimated to be affected by other functional components besides polyphenol compounds and anthocyanins because they were inconsistent with the trends of the total phenol, flavonoid, and anthocyanin contents.
\end{abstract}

Key words : Platycodon grandiflorum, physiological activities, polyphenol, anthocyanin, antioxidant

\section{서 론}

생활수준의 향상, 고령화 사회 진입과 같은 사회구조의 변화와 함께 식습관에 기인하는 만성질환의 증가로 식물체 가 가지고 있는 생리활성 성분(phytochemicals)에 의한 노화 예방이나 지연시키는 효과 및 질병 예방의 효과 등에 대한 관심이 높아지고 있고, well-being 문화가 정착됨에 따라 약용 및 식용식물을 이용한 기능성 식품의 개발과 활용에 관한 연구들이 활발히 이루어지고 있다(1-4).

도라지(Platycodon grandiflorum A. DC.)는 한국, 일본

*Corresponding author. E-mail : whanbee@daum.net Phone : 82-55-860-8947, Fax : 82-55-860-8960

Received 29 July 2019; Revised 29 August 2019; Accepted 02 September 2019.

Copyright (c) The Korean Society of Food Preservation. All rights reserved.
및 중국의 산간지방에 널리 자생하는 국화목에 해당하는 초롱꽃과(Campanulaceae) 초롱꽃속에 속하는 식물이다 $(5,6)$. 도라지는 7-8월에 꽃이 피며(7) 줄기를 삶아서 나물로 먹기도 하나 뿌리를 주로 활용하며, 거담이나 진해의 약재 로 사용되는 부분은 길경(桔梗)이라 지칭되는 뿌리이다 $(8,9)$. 도라지는 섬유질이 풍부하고 칼슘과 철이 많이 함유 된 알칼리성 식품으로써 $(4,10)$ 우리나라에서는 오래전부터 생채, 전, 나물 및 장 등으로 식용하여 왔으며, triterpenoid계 saponin 및 platycodin과 같은 주요 약리 성분에 기반하여 거담, 진해, 해열, 진통 등에 대하여 약용으로도 이용되어 왔다 $(4,11,12)$.

도라지 뿌리는 선행연구를 통해 면역력 증진(13), 항산화 (8), 항균 $(8,14)$, 항비만(15) 및 항당뇨(16) 효과 등의 기능성 연구와 건조온도(17), 건조방법(18) 및 저장방법과 기간(19) 에 따른 도라지 속 사포닌 성분의 변화 등의 연구가 다수 보고된 바 있다. 도라지의 잎, 줄기에서도 platycosides(20) 
와 더불어 항산화성 페놀 화합물(21,22)이 확인되어 기능성 소재로서의 활용 가능성이 제기되기도 하였고, 최근에는 종자의 영양학적 특성(23) 및 종자유 특성(24)과 같이 종자 에 대한 연구도 진행되어 있다. 이에 반해 도라지 꽃은 꽃차 의 소재로서 시중에 유통되고 있지만 이에 대한 영양학적 특성, 기능성 연구는 아직까지도 진행된 바 없다.

도라지 꽃은 흰색 또는 보라색으로 개화하는데, 각종 식 물의 잎, 꽃, 과실 등에서 적색, 자색, 청색에 이르는 다양한 색을 발현하는 색소성분으로는 페놀 화합물류인 안토시아 닌(anthocyanin)이 널리 알려져 있다 $(25,26)$. 안토시아닌은 인체 내 흡수 시 항산화 기능을 나타내 항암 작용에 관여하 고, 순환기질환 치료 및 염증 억제 등의 질환을 개선하는 것으로 보고되고 있다(27). 최근에는 유해성 문제로 사용이 규제되거나 금지되고 있는 합성색소를 대체하는 천연색소 로서 안토시아닌에 대한 연구개발이 진행되고 있다(26). 보라색의 도라지 꽃은 안토시아닌과 페놀성 화합물들에 기인하여 다양한 생리활성을 나타낼 수 있을 것으로 추정되 지만 약용식물로 그 쓰임이 높은 도라지 뿌리, 줄기와 비교 하여 활용도가 낮고, 생리활성과 관련하여서도 직접적인 연구결과가 부족하다. 본 연구에서는 도라지 꽃의 이용 가 능성 확인을 위한 기초 연구의 일환으로 산업적으로 적용 가능한 주정의 최대 농도를 $60 \%$ 로 설정하고, 그 이하의 농도로 주정 추출물을 제조하여 보라색 도라지 꽃의 이화학 적 특성 및 생리활성을 비교·분석 하였다.

\section{재료 및 방법}

\section{실험재료 및 추출물의 제조}

보라색 도라지 꽃은 남해군 두모마을 야생화 단지에서 직접 채취하여 세척한 후 꽃술과 꽃받침을 제거하고, $60^{\circ} \mathrm{C}$ 의 건조기에서 3 시간 정도 건조시켜 사용하였다. 추출에 사용된 주정은 우리주정사(Busan, Korea)의 95\% 발효주정 을 이용하였다.

세척하여 건조 한 보라색 도라지 꽃 약 $20 \mathrm{~g}$ 에 10,30 및 $60 \%$ 주정을 각 $2 \mathrm{~L}$ 씩 가하여 상온에서 3 일간 정치시켜 추출한 다음 여과지로 여과한 여액을 실험에 사용하였다.

\section{색 도}

각 추출액의 색은 색차계(Ultra scan VIS, Hunter Associates Laboratory Inc., Reston, VA, USA)로 측정하여 $\mathrm{L}, \mathrm{a}, \mathrm{b}, \Delta \mathrm{E}$ 값으로 나타내었다. 이 때 표준색판의 $\mathrm{L}, \mathrm{a}$, $\mathrm{b}$ 값은 각각 $99.41,-0.13$ 및 0.06 이었으며, 각 시료는 5회 이상 반복 측정하여 평균값으로 나타내었다.

탁도, $\mathrm{pH}$ 및 산도

시료액의 탁도는 침출 시료액을 일정량 취하여 분광광도
계(Libra S 35, Biochrom, Cambridge, England)를 이용하여 $600 \mathrm{~nm}$ 에서 탁도를 측정하여 흡광도 값으로 나타내었다. 추출액의 $\mathrm{pH}$ 와 산도는 시료에 정제수를 가하여 10 배 희석 한 후 여과한 여액 $50 \mathrm{~mL}$ 을 취하여 자동적정기(G20 compact titrator, Mettler toledo, Grefensee, Switzerland)를 이용해 동시에 분석하였다.

\section{총 페놀 화합물}

시료액의 총 페놀 화합물은 Gutfinger(28)의 방법에 따라 시료 추출 여과액 $1 \mathrm{~mL}$ 에 Foline-Ciocalteau 시약 $0.5 \mathrm{~mL}$ 를 넣고 3분 후 $10 \% \mathrm{Na}_{2} \mathrm{CO}_{3}$ 용액 $0.5 \mathrm{~mL}$ 씩을 가한 후 혼합하여 실온의 암실에서 1 시간 정치한 다음 분광광도계(Libra $\mathrm{S}$ 35, Biochrom, Cambridge, England)로 $760 \mathrm{~nm}$ 에서 흡광도를 측정하였다. 표준물질로 gallic acid(Sigma-Aldrich Co., St. Louis, MO, USA)를 사용하여 시료와 동일한 방법으로 분석 하여 얻은 표준곡선으로부터 총 페놀 화합물의 함량을 산출 하였다.

\section{총 플라보노이드}

총 플라보노이드 함량은 Lee 등(29)의 방법을 변형하여 시료액 $50 \mu \mathrm{L}$ 에 $1 \mathrm{~N} \mathrm{NaOH} 50 \mu \mathrm{L}$ 를 넣고 diethylene glycol $200 \mu \mathrm{L}$ 를 혼합하여 vortexing 한 후 $37^{\circ} \mathrm{C}$ 에서 5 분간 반응시 킨 다음 $420 \mathrm{~nm}$ 에서 흡광도를 측정하였다. 이 때 rutin (Sigma-Aldrich Co., St. Louis, MO, USA)을 표준물질로 하 여 얻은 표준곡선으로부터 총 플라보노이드 함량을 계산하 였다.

\section{총 안토시아닌}

총 안토시아닌 함량은 $\mathrm{AOAC}$ 방법에 의한 $\mathrm{pH}$ differential $\operatorname{method}(30)$ 를 변형하여 측정하였다. 96 well plate에 적당한 농도로 희석한 시료 $10 \mu \mathrm{L}$ 를 넣고 각각에 $2.5 \mathrm{mM}$ potassium chloride buffer(pH 1.0)와 $400 \mathrm{mM}$ sodium acetate buffer( $\mathrm{pH}$ 4.5) $190 \mu \mathrm{L}$ 씩을 넣고 $510 \mathrm{~nm}$ 와 $700 \mathrm{~nm}$ 에서 흡광도를 각각 3회 반복 측정하였다. 표준물질은 cyaniding-3-glucoside equivalents의 분자량과(MW)과 몰흡광계수( $\varepsilon=26,900 \mathrm{M}^{-1}$ $\mathrm{cm}^{-1}$ ) 값으로 부터 monomeric anthocyanin pigment 방법을 변형하여 산출하였다.

$$
\text { 총 안토시아닌 함량 }(\mathrm{mg} / 100 \mathrm{~g})=\frac{\mathrm{A} \times \mathrm{MW} \times 1000 \times \mathrm{V}}{\varepsilon}
$$

\section{$\mathrm{A}($ 흡광도 $)=(\mathrm{A} 510 \mathrm{~nm}-\mathrm{A} 700 \mathrm{~nm}) \mathrm{pH} 1.0-(\mathrm{A} 510 \mathrm{~nm}-\mathrm{A} 700$ $\mathrm{nm}) \mathrm{pH} 4.5$}

MW(cyanidin-3-glucoside의 분자량): 449.2

$\varepsilon$ (cyanidin-3-glucoside 분자 흡광도): $26,900 \mathrm{M}^{-1} \mathrm{~cm}^{-1}$ $\mathrm{V}$ : 시료의 최종부피 $(\mathrm{mL})$ 


\section{항산화 활성}

1,1-Diphenyl-2-picrylhydrazyl(DPPH) 라디칼 소거 활성 은 시료액의 $\mathrm{DPPH}$ 에 대한 전자공여 활성을 나타낸 것으로 Blois(31)의 방법을 응용하여 측정하였다. 즉, DPPH 용액(5 $\mathrm{mg} / 100 \mathrm{~mL}$ methanol) $100 \mu \mathrm{L}$ 와 시료 $100 \mu \mathrm{L}$ 를 혼합한 다음 실온에서 20분간 반응시킨 후 분광광도계(Perkin-Elmer Inc, Waltham, MA, USA)를 이용하여 $525 \mathrm{~nm}$ 에서 흡광도를 측정하였다. DPPH 라디칼 소거 활성은 시료 첨가구와 무첨 가구의 흡광도비로 나타내었다.

2,2-azinobis-(3-ethylbenzo-thiazoline-6-sulphonate)(ABTS) 라디칼 소거 활성은 $\operatorname{Re}$ 등(32)의 방법에 따라 $7 \mathrm{mM}$ 의 ABTS 용액에 potassium persulfate를 $2.4 \mathrm{mM}$ 이 되도록 용해 시킨 다음 암실에서 12-16시간 동안 반응시킨 후 $415 \mathrm{~nm}$ 에 서 흡광도가 1.5 가 되도록 증류수로 조정한 $\mathrm{ABTS}$ 용액을 사용하였다. ABTS 용액 $100 \mu \mathrm{L}$ 에 시료액 $100 \mu \mathrm{L}$ 를 혼합하 고 실온에서 5 분간 반응시킨 다음 분광광도계 (Perkin-Elmer Inc, Waltham, MA, USA)를 이용하여 415 $\mathrm{nm}$ 에서 흡광도를 측정한 후 시료 무첨가구에 대한 시료첨 가구의 흡광도비로 라디칼 소거활성(\%)을 산출하였다.

Ferric reducing antioxidant power(FRAP)법에 의한 항산 화 활성은 Benzie와 Strain(33)의 방법에 따라 측정하였다. $\mathrm{pH} 3.6$ 의 $300 \mathrm{mM}$ acetate buffer, $40 \mathrm{mM} \mathrm{HCl}$ 에 용해한 $10 \mathrm{mM}$ TPTZ(2,4,6-tripyridyl-s-triazine) 용액 및 $20 \mathrm{mM}$ $\mathrm{FeCl}_{3} \cdot 6 \mathrm{H}_{2} \mathrm{O}$ 를 각각 $10: 1: 1(\mathrm{v} / \mathrm{v} / \mathrm{v})$ 의 비율로 미리 혼합한 다 음 $37^{\circ} \mathrm{C}$ 의 수옥상에서 5 분 동안 가온하여 FRAP 측정용 기질을 제조하였다. 96 well plate에 시료액 $40 \mu \mathrm{L}$, FRAP 기질액 $100 \mu \mathrm{L}$ 및 증류수 $40 \mu \mathrm{L}$ 를 차례로 혼합하여 $37^{\circ} \mathrm{C}$ 에 서 4 분간 반응시킨 후 $593 \mathrm{~nm}$ 에서 흡광도를 측정하였으며, $\mathrm{FeSO}_{4}$ 로 작성한 검량곡선에 대입하여 환산하였다

\section{콜레스테롤 흡착 활성}

콜레스테롤 흡착 활성은 Soh 등(34)의 방법을 응용하여 kit시약(AM 202-k, Asan Pharm., Seoul, Korea)으로 측정하 였다. 시료액 $1 \mathrm{~mL}$ 에 콜레스테롤 $(300 \mathrm{mg} / \mathrm{dL}) 50 \mu \mathrm{L}$ 를 가하 여 $25^{\circ} \mathrm{C}$ 에서 20 분간 반응시킨 후 $0.1 \mathrm{M}$ hexadecyltrimethylammonium bromide(Sigma-Aldrich Co., St. Louis, $\mathrm{MO}$, USA) $50 \mu \mathrm{L}$ 를 첨가하여 $25,000 \times \mathrm{g}$ 에서 15 분간 원심분 리 시켰다. 상층액 $200 \mu \mathrm{L}$ 에 효소액 $1.5 \mathrm{~mL}$ 을 혼합한 후 $37^{\circ} \mathrm{C}$ 에서 5 분간 반응시킨 다음 $500 \mathrm{~nm}$ 에서 흡광도를 측정 하였으며, 시료 무첨가구에 대한 시료 첨가군의 흡광도 비 로써 콜레스테롤 흡착 활성(\%)을 나타내었다.

\section{a-Glucosidase 저해 활성}

a-Glucosidase 저해 활성은 Choe 등(35)의 방법을 응용하 여 측정하였다. 즉, $0.1 \mathrm{M}$ phosphate 완충용액 $(\mathrm{pH} 6.8)$ 에 용해한 $2.5 \mathrm{mM}$ 의 $\rho$-nitrophenyl-a-D-glucopyranoside $50 \mu \mathrm{L}$ 와 $0.2 \mathrm{unit} / \mathrm{mL}$ 의 a-glucosidase $50 \mu \mathrm{L}$ 및 농도별 시료액 $50 \mu \mathrm{L}$ 를 혼합하여 $37^{\circ} \mathrm{C}$ 에서 20 분간 반응시켰다. 반응 후 $0.1 \mathrm{M} \mathrm{NaOH} 100 \mu \mathrm{L}$ 를 가하여 반응을 정지시킨 다음 405 $\mathrm{nm}$ 에서 흡광도를 측정하였다. a-Glucosidase 저해 활성은 효소액을 첨가하지 않은 실험구의 흡광도 및 시료 무첨가구 의 흡광도를 각각 측정하여 그 비로부터 산출하였다.

\section{Xanthine oxidase(XO) 저해 활성}

$\mathrm{XO}$ 저해 활성은 Stirpe와 Corte(36)의 방법에 따라 측정 하였다. 각 추출물 $0.3 \mathrm{~mL}$ 와 $0.1 \mathrm{M}$ potassium phosphate buffer(pH 7.5)에 xanthine(Sigma-Aldrich Co., St. Louis, MO, USA) $2 \mathrm{mM}$ 을 녹인 기질액 $3 \mathrm{~mL}$ 를 혼합하였다. 여기에 $0.2 \mathrm{U} / \mathrm{mL}$ 농도의 $\mathrm{XO} 0.3 \mathrm{~mL}$ 를 가하여 $37^{\circ} \mathrm{C}$ 에서 30 분간 반응시킨 다음 $20 \%$ trichloroacetic acid $1 \mathrm{~mL}$ 를 가하여 반응 을 정지시킨 후, 반응액 중에 생성된 uric acid의 양을 292 $\mathrm{nm}$ 에서 측정하였다. 시료에 대한 XO 저해 활성은 시료용 액 첨가구와 무첨가구 간의 흡광도 감소율의 비를 백분율 (\%)로 나타내었다.

\section{통계처리}

모든 실험은 3회 이상 반복하여 실시하였으며 실험으로 부터 얻은 결과는 SPSS 12.0(SPSS Inc., Chicago, IL, USA) 을 사용하여 분석하였다. 결과치는 실험군당 평균표표준편 차로 표시하였고, 통계적 유의성 검정은 일원배치 분산분 석 한 후 $\mathrm{p}<0.05$ 수준에서 Duncan's multiple range test를 시행하였다.

Table 1. Hunter color value of Platycodon grandiflorum flower extract with different ratio of edible ethanol in extraction solvent

\begin{tabular}{ccccc}
\hline Ethanol content of extraction solvent (\%) & $\mathrm{L}$ & $\mathrm{a}$ & $\mathrm{b}$ & $\Delta \mathrm{E}$ \\
\hline 10 & $\left.43.00 \pm 0.57^{1) \mathrm{B} 2}\right)$ & $1.88 \pm 0.03^{\mathrm{A}}$ & $12.48 \pm 0.28^{\mathrm{B}}$ & $57.80 \pm 0.50^{\mathrm{B}}$ \\
30 & $45.13 \pm 0.11^{\mathrm{C}}$ & $2.44 \pm 0.02^{\mathrm{B}}$ & $17.58 \pm 0.03^{\mathrm{C}}$ & $57.10 \pm 0.10^{\mathrm{A}}$ \\
60 & $37.68 \pm 0.09^{\mathrm{A}}$ & $4.46 \pm 0.06^{\mathrm{C}}$ & $2.00 \pm 0.08^{\mathrm{A}}$ & $61.94 \pm 0.09^{\mathrm{C}}$ \\
\hline
\end{tabular}

Standard : $\mathrm{L}^{*}$ 99.42, $\mathrm{a}^{*}-0.12, \mathrm{~b}^{*} 0.05$.

${ }^{1)}$ All values are mean $\pm \mathrm{SD}(\mathrm{n}=3)$.

2)A-C Means with different superscript within the same column are significantly different by Duncan's multiple range test $(\mathrm{p}<0.05)$. 


\section{결과 및 고찰}

\section{색 도}

건조된 보라색 도라지 꽃에 물과 주정 $(\mathrm{v} / \mathrm{v})$ 의 혼합비율을 달리한 용매로 추출한 추출물의 색도를 측정하여 Table 1에 나타내었다. 추출물의 $\mathrm{L}$ 값은 $10 \%$ 주정 추출물과 $30 \%$ 주정 추출물에서 각각 43.00 과 45.13 으로 $30 \%$ 주정 추출물에서 더 높았고, $60 \%$ 주정 추출물은 37.68 로 다른 추출물들보다 유의적으로 $\mathrm{L}$ 값이 낮았다. a값은 $10 \%, 30 \%$ 및 $60 \%$ 주정 추출물이 각각 $1.88,2.44$ 및 4.46 으로 추출용매 중 주정의 비율에 비례하여 증가하는 경향이었다. 일반적으로 안토시 아닌의 함량이 높으면 적색 영역의 흡광도 및 색차계의 적색도가 증가하는 것으로 알려져 있다(37). 본 연구에서 추출용매 중 주정의 비율이 높아질수록 $\mathrm{a}$ 값이 증가한 것은 주정의 비율이 높을수록 항산화적 생리활성 물질이면서 식물의 색소성분인(38) 안토시아닌의 추출이 용이해졌기 때문으로 추정된다. $\mathrm{b}$ 값은 시료 추출물들이 각기 다른 값들 을 나타내었는데, $60 \%$ 주정 추출물은 2.00 으로 시료군 중 그 값이 가장 낮았고 $10 \%$ 주정 추출물의 $\mathrm{b}$ 값은 $12.48,30 \%$ 주정 추출물은 17.58 로 $\mathrm{L}$ 값이나 a값처럼 일정한 증감의 경향을 나타내지 않고 $30 \%$ 주정 추출물에서 가장 높았다.

\section{탁도, $\mathrm{pH}$ 및 산도}

도라지 꽃 주정 추출물의 탁도, $\mathrm{pH}$ 및 산도는 Table 2 와 같다. 추출물들의 탁도는 시료군 사이에 일정한 경향을 보 이지 않았는데, $60 \%$ 주정 추출물(65.13\%)이 $10 \%$ 주정 추출 물 $(80.40 \%)$ 과 $30 \%$ 주정 추출물(83.13\%)보다 각각 $15.27 \%$ 와 $18.00 \%$ 더 낮았다.

추출물들의 $\mathrm{pH}$ 는 6.17-6.61의 범위로 주정농도 의존적으 로 증가하는 경향이었다. 이와는 반대로 산도는 주정농도 에 의존하여 감소하는 경향이었는데, $30 \%$ 주정 추출물과 $60 \%$ 주정 추출물은 각각 $0.04 \%$ 와 $0.03 \%$ 였고, $10 \%$ 주정 추출물은 $0.05 \%$ 로 평균값은 차이가 있었으나 통계적인 유 의차는 없었다.

\section{총 페놀 화합물, 총 플라보노이드 및 총 안토시아닌 함량}

식물성 식품에 함유된 페놀성 분자들은 생체 내에서 항 산화, 항비만 및 항염증 등과 같은 다양한 기능을 가지고 있는 것으로 보고되어 있다(39,40). 플라보노이드는 식물체 의 페놀류계 물질 중 가장 중요한 화합물로 플라보노이드계 페놀 화합물이 많이 함유된 채소류 등을 매일 섭취하면 심혈관계 질환의 위험도를 감소시킨다는 임상결과도 보고 된 바 있다(41-43).

Table 3은 주정농도에 따른 보라색 도라지 꽃 추출물의 총 페놀 화합물, 총 플라보노이드 및 총 안토시아닌 함량을 측정한 결과이다. 추출물의 총 페놀 화합물 함량은 105.94-113.79 $\mathrm{\mu g} / \mathrm{mL}$ 였으며 60\% 주정 추출물> $30 \%$ 주정
추출물> $10 \%$ 주정 추출물 순으로 유의한 결과를 나타내었 다. 총 플라보노이드의 경우 $11.97-27.13 \mu \mathrm{g} / \mathrm{mL}$ 로 그 경향이 총 페놀 화합물과 일치하였으며, $60 \%$ 주정 추출물은 $10 \%$ 주정 추출물보다 총 플라보노이드 함량이 2.2 배 가량 더 높았다. $\operatorname{Kim}$ 과 $\operatorname{Kim}(44)$ 의 에탄올 농도(0-99.5\%)에 따른 돌 외 잎 차 추출물의 총 페놀 및 플라보노이드 함량을 측정한 결과에서도 본 연구와 같이 에탄올 농도에 비례하여 총 페놀 및 플라보노이드 함량이 유의하게 증가되었지만 $\mathrm{Oh}$ 등(45)이 등나무 보라색 꽃 추출물의 총 페놀 함량을 측정한 결과에서는 물 추출물이 에탄올 추출물보다 총 페놀 함량이 유의하게 높았다.

안토시아닌은 식물체에 존재하며 자색, 적색, 청색 등을 나타내는 천연 수용성 색소로 C6-C3-C6의 기본 골격을 갖 고 수산기의 수, 위치, 메틸화에 따라 다양한 종류가 자연계 에 존재하면서 식품의 색 등 관능적 품질 특성을 결정하고 항산화 활성 등을 가지는 것으로 알려져 있다 $(46,47)$.

총 안토시아닌 함량은 $10 \%$ 주정 추출물 $(0.01 \mathrm{\mu g} / \mathrm{mL})$ 과 $30 \%$ 주정 추출물 $(0.02 \mu \mathrm{g} / \mathrm{mL})$ 간에 통계적으로 유의한 차 이가 없었으나 $60 \%$ 주정 추출물에서는 $0.13 \mathrm{\mu g} / \mathrm{mL}$ 로 다른 추출물보다 유의적으로 높았다. Park 등(48)은 오디와 블루 베리 모두 물 추출물보다 $50 \%$ 에탄올 추출물에서 안토시아 닌과 총 페놀 및 플라보노이드 함량이 더 높았다고 보고한 바 있는데, 본 연구의 보라색 도라지 꽃 주정 추출물에서도 총 페놀 화합물, 플라보노이드 및 안토시아닌 함량은 모두 $60 \%$ 주정으로 추출한 것이 가장 높았다. 식물 추출물 제조 시에 물과 에탄올이 혼합된 에탄올 수용액 형태가 식물체로 의 침투용이성이 높아 페놀성 화합물 추출에 유리한 것으로 보고되어 있다(44).

\section{항산화 활성}

꽃 추출물은 잎 또는 종자 추출물과 비교하여 더 높은 페놀성 화합물, 안토시아닌류 등을 함유하고 있어 매우 우 수한 항산화 활성을 지닌다고 보고되어 있는데(49), Table 4-6은 주정의 첨가 비율 $(10 \%, 30 \%$ 및 $60 \%)$ 을 달리한 보라 색 도라지 꽃 추출물의 항산화 활성을 각기 다른 방법으로 측정한 후 그 결과를 나타낸 것이다.

DPPH 라디칼 소거활성(Table 4)은 세 시료 모두에서 농 도 의존적으로 증가하는 경향을 보였는데, $0.5 \mu \mathrm{g} / \mathrm{mL}$ 의 농 도에서 $12.11-15.81 \%$ 이던 것이 $10 \mu \mathrm{g} / \mathrm{mL}$ 농도에서는 84.93-89.95\%로 활성이 증가하였다. DPPH 라디칼 소거활 성은 동일한 시료 농도에서는 $60 \%$ 주정 추출물에서 가장 높았고, 다음으로 $10 \%$ 주정 추출물에서 높아 추출 용매의 주정 농도에 비례하여 활성에 차이가 있지는 않았다.

$\mathrm{ABTS}$ 라디칼 소거활성을 측정한 결과(Table 5) 또한 시 료의 농도에 비례하여 그 활성이 증가한다는 점은 $\mathrm{DPPH}$ 라디칼 소거활성과 같았지만 활성의 절대 값은 더 높아 $5 \mu \mathrm{g} / \mathrm{mL}$ 농도에서 활성은 $92 \%$ 이상이었다. 또한 $\mathrm{DPPH}$ 
Table 2. Turbidity, $\mathrm{pH}$ and acidity of Platycodon grandiflorum flower extract with different ratio of edible ethanol in extraction solvent

\begin{tabular}{cccc}
\hline Ethanol content of extraction solvent (\%) & Turbidity (\%) & $\mathrm{pH}$ & Acidity $(\%)$ \\
\hline 10 & $80.40 \pm 0.85^{\left.1)^{B 2}\right)}$ & $6.17 \pm 0.07^{\mathrm{A}}$ & $0.05 \pm 0.01^{\mathrm{A}}$ \\
30 & $83.13 \pm 0.06^{\mathrm{C}}$ & $6.59 \pm 0.05^{\mathrm{B}}$ & $0.04 \pm 0.01^{\mathrm{A}}$ \\
60 & $65.13 \pm 0.31^{\mathrm{A}}$ & $6.61 \pm 0.05^{\mathrm{B}}$ & $0.03 \pm 0.01^{\mathrm{A}}$ \\
\hline
\end{tabular}

${ }^{1)}$ All values are mean $\pm \mathrm{SD}(\mathrm{n}=3)$

${ }^{2) A-C}$ Means with different superscript within the same column are significantly different by Duncan's multiple range test $(p<0.05)$.

Table 3. Total phenolic compounds, flavonoid and anthocyanin contents of Platycodon grandiflorum flower extract with different ratio of edible ethanol in extraction solvent

\begin{tabular}{cccc}
\hline Ethanol content of extraction solvent $(\%)$ & Total phenolic compounds $(\mu \mathrm{g} / \mathrm{mL})$ & Total flavonoid $(\mu \mathrm{g} / \mathrm{mL})$ & Anthocyanin $(\mu \mathrm{g} / \mathrm{mL})$ \\
\hline 10 & $105.94 \pm 0.22^{1) A 2}$ & $11.97 \pm 0.17^{\mathrm{A}}$ & $0.01 \pm 0.03^{\mathrm{A}}$ \\
30 & $107.79 \pm 0.10^{\mathrm{B}}$ & $16.08 \pm 0.26^{\mathrm{B}}$ & $0.02 \pm 0.02^{\mathrm{A}}$ \\
60 & $113.79 \pm 0.10^{\mathrm{C}}$ & $27.13 \pm 0.96^{\mathrm{C}}$ & $0.13 \pm 0.04^{\mathrm{B}}$ \\
\hline
\end{tabular}

${ }^{1)}$ All values are mean $\pm \mathrm{SD}(\mathrm{n}=3)$.

${ }^{2) A-C}$ Means with different superscript within the same column are significantly different by Duncan's multiple range test $(\mathrm{p}<0.05)$.

Table 4. DPPH radical scavenging activity of Platycodon grandiflorum flower extract with different ratio of edible ethanol ethanol in extraction solvent

$(\%)$

\begin{tabular}{cccccc}
\hline \multirow{2}{*}{$\begin{array}{c}\text { Ethanol content of } \\
\text { extraction solvent }(\%)\end{array}$} & \multicolumn{5}{c}{ Sample concentration $(\mu \mathrm{g} / \mathrm{mL})$} \\
\hline & 0.5 & 1 & 2 & 5 & 10 \\
\hline 10 & $13.84 \pm 0.17^{1) 22) \mathrm{B} 3)}$ & $22.47 \pm 0.46^{\mathrm{bB}}$ & $37.54 \pm 0.41^{\mathrm{CB}}$ & $73.22 \pm 0.31^{\mathrm{dB}}$ & $89.11 \pm 0.05^{\mathrm{eB}}$ \\
30 & $12.11 \pm 0.31^{\mathrm{aA}}$ & $18.96 \pm 0.28^{\mathrm{bA}}$ & $31.48 \pm 0.63^{\mathrm{cA}}$ & $62.95 \pm 1.09^{\mathrm{dA}}$ & $84.93 \pm 0.29^{\mathrm{eA}}$ \\
60 & $15.81 \pm 0.06^{\mathrm{aC}}$ & $26.01 \pm 1.07^{\mathrm{bC}}$ & $45.62 \pm 0.66^{\mathrm{CC}}$ & $76.79 \pm 0.63^{\mathrm{dC}}$ & $89.95 \pm 0.20^{\mathrm{eC}}$ \\
\hline \multirow{2}{*}{ Positive control } & \multicolumn{7}{c}{ Ascorbic acid concentration $(\mu \mathrm{g} / \mathrm{mL})$} \\
\cline { 2 - 6 } & 1.6 & 6.3 & 12.5 & 25.0 \\
\hline Activity (\%) & $5.22 \pm 0.40$ & $10.89 \pm 0.37$ & $23.61 \pm 0.03$ & $47.00 \pm 0.17$ & $88.33 \pm 0.44$ \\
\hline
\end{tabular}

${ }^{1)}$ All values are mean \pm SD $(n=4)$.

2)a-e Means with different superscript within the same row are significantly different by Duncan's multiple range test $(p<0.05)$.

${ }^{3) A-C}$ Means with different superscript within the same column are significantly different by Duncan's multiple range test $(\mathrm{p}<0.05)$.

Table 5. ABTS radical scavenging activity of Platycodon grandiflorum flower extract with different ratio of edible ethanol in extraction solvent

$(\%)$

\begin{tabular}{cccccc}
\hline \multirow{2}{*}{$\begin{array}{c}\text { Ethanol content of } \\
\text { extraction solvent (\%) }\end{array}$} & \multicolumn{5}{c}{ Sample concentration $(\mu \mathrm{g} / \mathrm{mL})$} \\
\hline 10 & 0.5 & 1 & 2 & 5 & 10 \\
\hline 30 & $20.36 \pm 0.53^{1) 22) \mathrm{A} 3)}$ & $37.10 \pm 0.68^{\mathrm{bA}}$ & $61.54 \pm 0.71^{\mathrm{CB}}$ & $93.02 \pm 0.73^{\mathrm{dA}}$ & $97.43 \pm 0.20^{\mathrm{eA}}$ \\
60 & $22.94 \pm 0.58^{\mathrm{aB}}$ & $37.24 \pm 0.53^{\mathrm{bA}}$ & $60.68 \pm 0.38^{\mathrm{cA}}$ & $92.66 \pm 1.33^{\mathrm{dA}}$ & $97.18 \pm 0.05^{\mathrm{eA}}$ \\
\hline Positive control & $28.00 \pm 0.24^{\mathrm{aC}}$ & $47.18 \pm 0.68^{\mathrm{bB}}$ & $77.30 \pm 0.18^{\mathrm{cC}}$ & $97.14 \pm 0.07^{\mathrm{dB}}$ & $97.39 \pm 0.04^{\mathrm{dA}}$ \\
\hline \multicolumn{7}{c}{ Ascorbic acid concentration $(\mu \mathrm{g} / \mathrm{mL})$} \\
\hline Activity $(\%)$ & 1.6 & 6.3 & 12.5 & 25.0 \\
\hline
\end{tabular}

${ }^{1)}$ All values are mean $\pm \mathrm{SD}(\mathrm{n}=4)$.

${ }^{2) a-e}$ Means with different superscript within the same row are significantly different by Duncan's multiple range test $(\mathrm{p}<0.05)$.

${ }^{3) A-C}$ Means with different superscript within the same column are significantly different by Duncan's multiple range test $(\mathrm{p}<0.05)$. 
라디칼 소거활성은 $30 \%$ 주정 추출물이 $10 \%$ 주정 추출물에 비해 유의적으로 낮았으나 ABTS 라디칼 소거활성은 일부 농도에서는 서로 간에 유의적인 차이가 없거나 다소 높았다.

Nakamura 등(50)이 에탄올 농도별 당유자 잎 추출물의 항산화 활성을 측정한 결과에서도 본 결과와 같이 $\mathrm{DPPH}$ 라디칼 소거활성 경향과 $\mathrm{ABTS}$ 라디칼 소거활성 경향이 일치하지 않았다. DPPH 라디칼은 반응성이 높은 수산기만 반응하지만 ABTS 라디칼은 수산기에 대한 선택성이 낮아 $\mathrm{DPPH}$ 라디칼 소거 활성에서 반응하지 않았던 물질이 소거 활성에 관여한다고 보고된 바 있다(50,51). 이와 같은 이유 에서 본 연구의 DPPH 라디칼 소거활성 측정결과와 $\mathrm{ABTS}$ 라디칼 소거활성 경향이 일치하지 않은 것으로 추정된다.

FRAP 법에 의한 항산화력은 DPPH 라디칼 소거활성과 높은 상관관계를 나타낸다고 보고되어 있는데(52), 본 연구 에서 보라색 도라지 꽃 추출물의 FRAP(Table 6)는 농도
의존적으로 증가하고 $0.5-10 \mu \mathrm{g} / \mathrm{mL}$ 의 농도에서 $60 \%$ 주정 추출물> $10 \%$ 주정 추출물> $30 \%$ 주정 추출물 순으로 활성 이 높아 DPPH 라디칼 소거활성과 유사한 경향이었다.

본 연구의 보라색 도라지 꽃 추출물의 항산화 활성 측정 결과 세 항목 모두 $60 \%$ 주정을 첨가하여 시료를 추출하였 을 때 항산화 활성이 가장 높았으나 $10 \%$ 와 $30 \%$ 주정 추출 물 간에는 주정의 첨가 농도에 따른 일관된 경향이 확인되 지 않았다.

$60 \%$ 주정 추출물의 항산화 활성이 높은 것은 일반적으로 페놀성 화합물이 항산화 활성에 기여한다는 보고(53)와 아 로니아 추출물이 총 안토시아닌 함량 및 총 페놀 화합물 함량에 기인하여 높은 항산화 활성을 가진다는 Lidija 등 (54)의 보고로 미루어 볼 때 페놀성 화합물을 중심으로 한 항산화성 물질의 영향인 것으로 추정된다. $10 \%$ 와 $30 \%$ 주 정 추출물에서는 페놀류 외에도 비타민류 같은 수용성 성분

Table 6. FRAP of Platycodon grandiflorum flower extract with different ratio of edible ethanol in extraction solvent

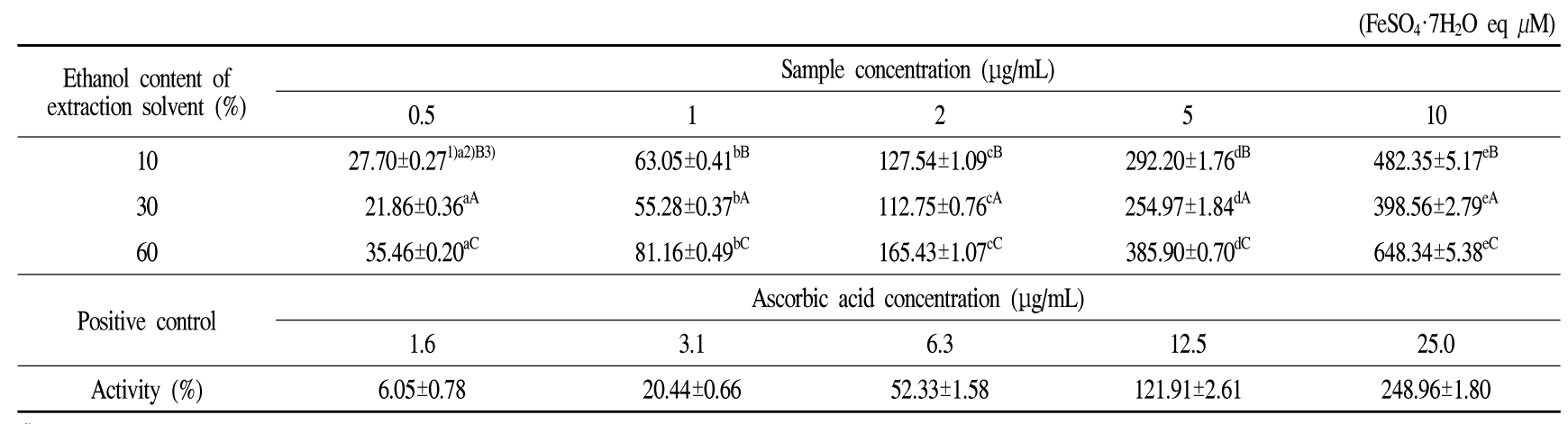

${ }^{1)}$ All values are mean \pm SD $(n=4)$.

2)a-e Means with different superscript small letters within the same row are significantly different by Duncan's multiple range test ( $\mathrm{p}<0.05$ ).

${ }^{3) A-C}$ Means with different superscript capital letters within the same column are significantly different by Duncan's multiple range test ( $p<0.05$ ).

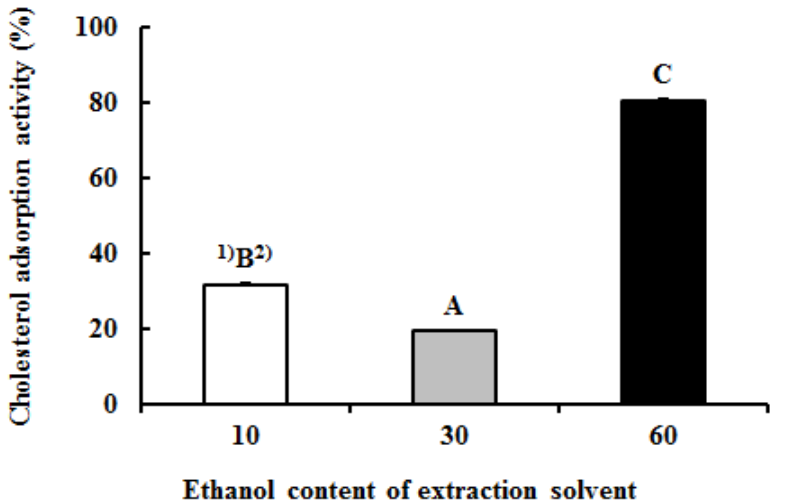

Fig. 1. Cholesterol adsorption activity of Platycodon grandiflorum flower extract with different ratio of edible ethanol in extraction solvent.

Sample concentration is $10 \mu \mathrm{g} / \mathrm{mL}$.

All values are mean \pm SD $(n=4)$.

$1)^{A-C}$ Means with different superscript within the same column are significantly different by Duncan's multiple range test $(\mathrm{p}<0.05)$.
들이 함께 용출되어 항산화 활성에 영향을 미치기 때문(55) 에 이들의 복합적인 상호작용으로 인해 활성에 차이를 보이 는 것으로 생각된다.

\section{콜레스테롤 흡착 활성}

주정 첨가 비율에 따른 보라색 도라지 꽃 추출물의 콜레 스테롤 흡착 활성을 측정한 결과는 Fig. 1 과 같다. $10 \%$ 주정 추출물의 콜레스테롤 흡착 활성은 $31.77 \%, 30 \%$ 주정 추출 물은 $19.43 \%, 60 \%$ 주정 추출물은 $80.66 \%$ 로 시료군 간의 활성 차가 매우 큰 것을 확인할 수 있었으며, 보라색 도라지 꽃 추출물의 콜레스테롤 흡착 활성 경향은 항산화 활성 경향과 전반적으로 일치하였다. 이와 같은 결과로 미루어 보면 $60 \%$ 주정 추출물이 $10 \%$ 및 $30 \%$ 주정 추출물보다 콜레스테롤 흡착 활성이 월등히 높아 체내 지질수준 감소에 유효한 제품의 개발에 더 유리할 것으로 예상된다. 


\section{a-Glucosidase 저해 활성}

a-Glucosidase는 식후 탄수화물이 a-amylase에 의해 변형 된 이당류를 단당류로 가수분해할 때 관여하는 효소로 소장 에서 흡수되어 각 장기에서 사용되지만 빠르게 흡수되면 혈당치가 높아져 다양한 질환을 유발하는 것으로 보고되어 있다(50). a-Glucosidase 저해제는 섭취한 탄수화물의 흡수 를 저지하고 체외로 배출시킴으로써 식후 혈당강하 효과를 가져(56) 당뇨, 비만 등 대사성 질환 치료제로 관심을 받고 있다(57).

Table 7은 주정 첨가 비율에 따른 보라색 도라지 꽃 추출 물의 a-glucosidase 저해 활성을 측정한 결과이다. 시료액의 a-glucosidase 저해 활성은 $0.5 \mu \mathrm{gg} / \mathrm{mL}$ 농도에서 51.28 $60.42 \%$ 이던 것이 $2 \mu \mathrm{g} / \mathrm{mL}$ 의 농도에서는 $71.91-86.11 \%$ 로 농도 의존적으로 활성이 증가하였다. 주정 첨가 비에 따라 서는 모든 농도에서 $10 \%$ 주정 추출물> $30 \%$ 주정 추출물> $60 \%$ 주정 추출물의 순으로 활성에 유의적인 차이가 있었는 데, 이는 항산화 활성이나 콜레스테롤 흡착 활성과는 상이 한 경향이었다.

일반적으로 폴리페놀과 사포닌계 화합물, phenolic acid 계 및 플라보노이드계 화합물이 a-glucosidase 저해 활성과 도 높은 상관관계를 가지는 것으로 보고되어 있다 $(58,59)$. 하지만 본 연구에서는 a-glucosidase 저해 활성이 페놀 함량 과의 연관성이 $\mathrm{r}=0.330$ 으로 유의성이 없었다는 Nakamura
등(50)의 보고와 같이 시료액의 총 페놀 화합물 함량과 $a$ -glucosidase 저해 활성은 경향과 상반되는 결과를 나타내 었다.

Mohamed 등(60)은 쿠미스쿠친(Orthosiphon stamineus) 의 에탄올 추출물에 대한 a-glucosidase 저해 활성을 조사한 결과 페놀이나 플라보노이드 외에 배당체나 탄수화물들도 a-glucosidase 저해 활성에 기여하고 있다는 점을 시사한 바 있는데 보라색 도라지 꽃 주정 추출물의 a-glucosidase 저해 활성은 페놀성 화합물보다 다른 기능성 성분이 영향을 주는 것으로 판단된다.

\section{Xanthine oxidase(XO) 저해 활성}

$\mathrm{XO}$ 는 생체 내 퓨린 대사에 관여하는 효소로서 xanthine 또는 hypoxanthine으로부터 요산을 생성하며 이 과정에서 활성산소종을 생성하고 통풍과 관련한 고요산혈증에 결정 적인 역할을 하는 것으로 알려져 있다 $(61,62)$.

Table 8은 보라색 도라지 꽃 주정 추출물 $5 \mu \mathrm{g} / \mathrm{mL}$ 와 10 $\mu \mathrm{g} / \mathrm{mL}$ 에 대한 $\mathrm{XO}$ 저해 활성을 측정한 결과이다. 시료 농도 가 $10 \mu \mathrm{g} / \mathrm{mL}$ 일 때 $\mathrm{XO}$ 저해 활성은 62.28-64.76\%로 $5 \mu \mathrm{g} / \mathrm{mL}$ 농도에서의 활성(55.38-56.84\%)보다 유의하게 더 높았다. 시료 농도 $5 \mu \mathrm{g} / \mathrm{mL}$ 에서는 모든 시료군 간에 추출액의 주정 첨가 비율에 따른 활성에 유의한 차이가 없었으나 $10 \mu \mathrm{g} / \mathrm{mL}$ 농도에서는 $60 \%$ 주정 추출물이 $10 \%$ 및 $30 \%$ 주정 추출물보

Table 7. a-Glucosidase inhibitory activity of Platycodon grandiflorum flower extract with different ratio of edible ethanol in extraction solvent

(\%)

\begin{tabular}{cccc}
\hline Ethanol content of extraction solvent & \multicolumn{3}{c}{ Sample concentration $(\mu \mathrm{g} / \mathrm{mL})$} \\
\cline { 2 - 4 }$(\%)$ & 0.5 & 1 & 2 \\
\hline 10 & $60.42 \pm 0.16^{1 / 2)(\mathrm{C})}$ & $75.49 \pm 0.07^{\mathrm{bC}}$ & $86.11 \pm 0.16^{\mathrm{CC}}$ \\
30 & $52.64 \pm 1.02^{\mathrm{aB}}$ & $68.18 \pm 1.23^{\mathrm{bB}}$ & $80.03 \pm 0.59^{\mathrm{BB}}$ \\
60 & $51.28 \pm 0.92^{\mathrm{aA}}$ & $63.08 \pm 0.92^{\mathrm{bA}}$ & $71.91 \pm 0.20^{\mathrm{cA}}$ \\
\hline
\end{tabular}

\footnotetext{
${ }^{1)}$ All values are mean \pm SD $(n=4)$.

2)acc Means with different superscript small letters within the same row are significantly different by Duncan's multiple range test $(\mathrm{p}<0.05)$.

3)A-C Means with different superscript capital letters within the same column are significantly different by Duncan's multiple range test $(p<0.05)$.
}

Table 8. Xanthin oxidase inhibitory activity of Platycodon grandiflorum flower extract with different ratio of edible ethanol in extraction solvent

(\%)

\begin{tabular}{ccc}
\hline \multirow{2}{*}{ Ethanol content of extraction solvent $(\%)$} & \multicolumn{2}{c}{ Sample concentration $(\mu \mathrm{g} / \mathrm{mL})$} \\
\cline { 2 - 3 } & 5 & $\left.62.28 \pm 1.05^{\mathrm{A}^{*} 3}\right)$ \\
30 & $55.95 \pm 0.78^{1) \mathrm{A} 2)}$ & $62.29 \pm 1.17^{\mathrm{A}^{* *}}$ \\
60 & $56.84 \pm 0.72^{\mathrm{A}}$ & $64.76 \pm 0.77^{\mathrm{B}^{* *}}$ \\
\hline
\end{tabular}

\footnotetext{
${ }^{1)}$ All values are mean \pm SD $(\mathrm{n}=4)$.

2)A-C Means with different superscript capital letters within the same column are significantly different by Duncan's multiple range test $(\mathrm{p}<0.05)$

${ }^{3)^{* *}} \mathrm{p}<0.01$, versus $5 \mu \mathrm{g} / \mathrm{mL}$ extract.
} 
다 $\mathrm{XO}$ 저해 활성이 유의하게 높았다.

Lee 등(63)은 산딸나무 열매추출물의 XO 저해 활성을 측정한 결과에서 ethanol 추출물은 물 추출물에 비해 저해 율이 상대적으로 높았다고 보고하였다. 또한 XO 저해 활성 은 폴리페놀 함량과 높은 상관관계를 보인다고 보고된 바 있는데 $(64,65)$, 본 연구의 결과 또한 시료구 간의 활성 차가 크지는 않았으나 $10 \mu \mathrm{g} / \mathrm{mL}$ 농도에서 시료구 중 총 페놀 화합물의 함량이 유의하게 가장 높았던 $60 \%$ 주정 추출물의 $\mathrm{XO}$ 저해 활성이 다른 추출물들보다 유의하게 높았다.

\section{요 약}

보라색 도라지 꽃의 기능성을 확인하기 위한 연구의 일 환으로 건조된 도라지 꽃에 10,30 및 $60 \%$ 주정을 가하여 추출한 후 이화학적 특성과 생리활성을 확인하였다. 추출 물들의 색도 중 $\mathrm{a}$ 값은 주정농도 의존적으로 증가하였으며, $\mathrm{pH}$ 도 동일한 경향이었다. 반면 산도는 주정농도에 의존하 여 감소하는 경향이었다. 식물체의 기능성 성분인 총 페놀 화합물, 총 플라보노이드 및 총 안토시아닌 함량은 각각

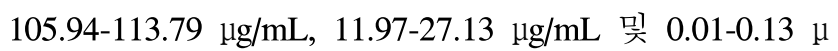
$\mathrm{g} / \mathrm{mL}$ 였으며, 모두 $60 \%$ 주정 추출물> $30 \%$ 주정 추출물> $10 \%$ 주정 추출물 순으로 유의하게 높았다. 항산화 활성과 콜레스테롤 흡착 활성은 $60 \%$ 주정 추출물이 $10 \%$ 및 $30 \%$ 주정 추출물에 비해 유의하게 높았다. a-glucosidase 저해 활성은 $10 \%$ 주정 추출물> $30 \%$ 주정 추출물> $60 \%$ 주정 추출물 순으로 유의한 차이가 있었다. 반면 xanthine oxidase 저해 활성은 주정 첨가 비율에 따른 유의적인 차이를 확인 할 수 없었다. 주정 첨가 비율을 달리한 보라색 도라지 꽃 주정 추출물들의 생리활성 지표들은 총 페놀 화합물, 총 플라보노이드 및 총 안토시아닌 함량과 모두 일치하지는 않았는데, 이로부터 보라색 도라지 꽃 주정 추출물들의 생 리활성에는 플라보노이드를 비롯한 폴리페놀 화합물, 안토 시아닌 외에도 여러 기능성 성분들이 복합적으로 작용하는 것으로 추정된다.

\section{감사의 글}

본 논문은 남해군에서 수행 한 문화체육관광부 야생화관 광자원화 사업 수행 결과의 일부이며 연구비 지원에 감사드 립니다.

\section{References}

1. Park SH, Hwang HS, Han JH (2004) Development of drink from composition with medicinal plant and evaluation of its physiological function. J Nutr Health, 37, 364-372

2. Kim AJ, Han MR, Joung KH, Cho JC, Park WJ, Han CW, Chang KH (2008) Physiological evaluation of Korean Ginseung, Deoduk and Doragi pickles. Korean J Food Nutr, 21, 443-447

3. Jeon SH, No IR, Kim YG, Cho YS (2017) Effect of mluching on the growth and medicinal ingredients of Platycodon grandiflorum radix organic cultivation. Korean J Org Agric, 25, 187-201

4. Lee SJ, Shin SR, Yoon KY (2013) Physicochemical properties of black Doraji (Platycodon grandiflorum). Korean J Food Sci Technol, 45, 422-427

5. Lim KH (1971) A Medicinal Phytology (The details). Dongmyeongsa Press, Gyeonggi-Do, Korea, p 281

6. Kim JY, Na HS, Choi PS (2017) Plant regeneration via adventitious shoot formation in Platycodon grandiflorum (Jacq. A. DC.). J Plant Biotechnol, 44, 330-334

7. Kang DK, Kim EJ, Park YJ, Kim TJ, Kim MR (2017) Comparison of antioxidant activities and quality characteristics between domestic diploid variety and tetraploid 'Etteum' variety in Platycodon grandiflorum. J Korean Soc Food Sci Nutr, 46, 196-201

8. Lee SJ, Bang WS, Hong JY, Kwon OJ, Shin SR, Yoon KY (2013) Antioxidant and antimicrobial activities of black Doraji (Platycodon grandiflorum). Korean J Food Preserv, 20, 510-517

9. Kim SY, Lee YJ, Park DS, Kim HR, Cho YS (2015) Comparison of quality characteristics of Platycodon grandiflorum according to steaming and fermentation. Korean J Food Preserv, 22, 851-858

10. Chung JH, Shin PG, Ryu JC, Jang DS, Cho SH (1997) Chemical compositions of Platycodon grandiflorus (jacquin) A. De Candolle. Agr Chem Biotechnol, 40, 148-151

11. Shon MY, Seo JK, Kim HJ, Sung NJ (2001) Chemical compositions and physiological activities of Doraji (Platycodon grandiflorum). J Korean Soc Food Sci Nutr, 30, 717-720

12. Han EH, Son YW, Kim MB, Shin YW, Cho YS, Lee SW (2014) Establishment of tissue culture and acclimation of white ballon flower (Platycodon grandiflorum DC. cv. Jangback) for the raising of in vitro propagated seedlings. J Plant Biotechnol, 41, 134-139

13. Ryu HS (2014) Effects of water extract from Platycodon grandiflorum on mouse immune cell activation ex vivo 
by oral administration. Korean J Food Nutr, 27, 99-104

14. Kim J (2014) Antibacterial and anti-inflammatory effects of Platycodon grandiflorum extracts. J Digital Convergence, 12, 359-366

15. Kang YH, Kim KK, Kim TW, Yang CS, Choe M (2015) Evaluation of the anti-obesity activity of Platycodon grandiflorum root and Curcuma longa root fermented with Aspergillus oryzae. Korean J Food Sci Technol, 47, 111-118

16. Kim OK (2016) The effect of Platycodon grandiflorum root ethanol extract on blood glucose, lipid, activities of carbohydrate metabolism related enzyme in streptozotocin-induced diabetic rats. J of Korean Oil Chemists' Soc, 33, 686-692

17. Lee BJ, Cho YS (2014) Effects of drying temperature on the saponin and free sugar contents of Platycodon grandiflorum radix. Korean J Food Sci Technol, 46, 769-772

18. Lee BJ, Jeon SH, Lee SW, Chun HS, Cho YS (2014) Effect of drying methods on the saponin and mineral contents of Platycodon grandiflorum raadix. Korean J Food Sci Technol, 46, 636-640

19. Lee BJ, Shin YY, Lee SW, Chun HS, Cho YS (2014) Effects of storage methods and periods on root hardness and content of saponin in Platycodon grandiflorum radix. Korean J Crop Sci, 59, 134-138

20. Lee JW, Ji SH, Kim GS, Song KS, Um Y, Kim OT, Lee Y, Hong CP, Shin DH, Kim CK, Lee SE, Ahn YS, Lee DY (2015) Global profiling of various metabolites in Platycodon grandiflorum by UPLC-QTOF/MS. Int J Mol Sci, 16, 26786-26796

21. Jeong CH, Shim KH (2006) Chemical composition and antioxidative activities of Platycodon grandiflorum leaves and stems. J Korean Soc Food Sci Nutr, 35, 511-515

22. Jeong $\mathrm{CH}$, Choi GN, Kim JH, Kwak JH, Kim DO, Kim YJ, Hoe HJ (2010) Antioxidant activities from the aerial parts of Platycodon grandiflorum. Food Chem, 118, 278-282

23. Kim YJ, Woo HR, Imm JY, Kim SJ (2018) Evaluation of nutritional characteristics of Platycodon grandiflorum seeds. KOCS, 35, 478-484

24. Kim YJ, Imm JY, Kim SJ (2018) Characterization of Platycodon grandiflorum seeds oil extracted by supercritical carbon dioxide. KOCS, 35, 99-110

25. Choi SJ (2010) The difference of anthocyanin pigment composition and color expression in fruit skin of several grape cultivars. Korean J Food Preserv, 17, 847-852

26. Kim HJ, Wee JH, Yang EJ (2015) Optimal conditions for anthocyanin extraction from black rice bran and storage stability of anthocyanin extract. J Korean Soc Food Sci Nutr, 44, 1543-1549

27. Jeong JC, Kim SJ, Honh SY, Nam JH, Sohn HB, Kim YH, Mekapogu M (2015) Growing environment influence the anthocyanin content in purple- and red-fleshed potatoes during tuber development. Korean J Crop Sci, 60, 231-238

28. Gutfinger T (1958) Polyphenols in olive oils. JAOCS, 58, 966-968

29. Lee YC, Hwang KH, Han DH, Kim SD (1997) Compositions of Opuntia ficus-indica. Korean J Food Sci Technol, 29, 847-853

30. Song JH, Cheong EJ, Kim HS, Kim MS, Kim SH (2015) Variation of morphological characteristics and anthocyanin contents from fruit of Vaccinium oldhamii in Korea. J Korean For Soc, 104, 193-197

31. Blois MS (1958) Antioxidant determination by the use of a stable free radical. Nature, 181, 1199-1200

32. Re R, Pellegrini N, Proteggente A, Pannala A, Yang M, Rice-Evans C (1999) Antioxidant activity applying an improved ABTS radical cation decolorization assay. Free Radical Biol Med, 26, 1231-1237

33. Benzie IFF, Strain JJ (1996) The ferric reducing ability of plasma (FRAP) as a measure of "antioxidant power": The FRAP assay. Anal Biochem, 239, 70-76

34. Soh HS, Kim CS, Lee SP (2003) A new in vitro assay of cholesterol adsorption by food and microbial polysaccharides. J Med Food, 6, 225-230

35. Choe M, Kim DJ, Lee HJ, You JK, Seo DJ, Lee JH, Chung MJ (2008) A study on the glucose-regulating enzymes and antioxidant activities of water extracts from medicinal herbs. J Korean Soc Food Sci Nutr, 37, 542-547

36. Stirpe F, Corte Della E (1970) The regulation of rat liver xanthine oxidase: conversion of type D (dehydrogenase) into type $\mathrm{O}$ (oxidase) by a thermolabile factor, and reversibility by dithioerythritol. Biochim Biophys Acta, 212, 195-197

37. Choung MG, Hwang YS, Lee HJ, Choi SSN, Lim JD, Kang ST, Han WY, Baek IY, Kim HK (2008) Optimal extraction condition of anthocyanins in soybean (Glycine max) with black seed coats. Korean J Crop Sci, 53, 110-117

38. Choi IS, Moon YS, Kwak EJ (2012) Composition of resveratrol and other bioactive compounds, and 
antioxidant activities in different mulberry cultivars. Kor J Hort Sci Technol, 30, 301-307

39. Cho YJ, Ju IS, Kim BC, Lee WS, Kim MJ, Lee BG, An BJ, Kim JH, Kwon OJ (2007) Biological activity of Omija (Schizandra chinensis Baillon) extracts. J Korean Soc Appl Biol Chem, 50, 198-203

40. Park SJ, Kwon SP, Rha YA (2017) Antioxidative activities and whitening effects of ethanol extract from Crataegus pinnatifida Bunge fruit. J Korean Soc Food Nutr, 46, 1158-1163

41. Cook NC, Samman S (1996) Flavonoids-chemistry, metabolism, cardioprotective effects, and dietary sources. J Nutr Biochem, 7, 66-76

42. Knekt P, Jarvinen R, Reunanen A, Maatela J (1996) Flavonoid intake and coronary mortality in Finland: a cohort study. Br Med J, 312, 478-481

43. Kang BT, Kwon DH, Choi WJ, Kim SH, Park DC (2008) Antioxidant and antiviral activities of polyphenolics in plum wine. Korean J Food Preserv, 15, 891-896

44. Kim KC, Kim JS (2019) Physiological activity of the extract from Dolwoe (Gynostemma pentaphyllum Makino) leaves tea by different ethanol concentrations. J Plant Biotechnol, 46, 37-44

45. Oh WG, Jang IC, Jeon GI, Park EJ, Park HR, Lee SC (2008) Antioxidant activity of extracts from Wisteria floribunda flowers. J Korean Soc Food Sci Nutr, 37, 677-683

46. Amorini AM, Lazzarino G, Galvano F, Fazzina G, Tavazzi B, Galvano G (2003) Cyanidin-3-o-betaglucopyranoside protects myocardium and erythrocytes from oxygen radical-mediated damages. Free Radic Res, 37, 453-460

47. Lee SM, You YH, Kim KM, Park JJ, Jeong CS, Jhon DY, Jun WJ (2012) Antioxidant activities of native Gwangyang Rubus coreanus Miq. J Korean Soc Food Sci Nutr, 41, 327-332

48. Park HM, Yang SJ, Kang EJ, Lee DH, Kim DI, Hong JH (2012) Quality characteristics and granule manufacture of mulberry and blueberry fruit extracts. Korean J Food Cookery Sci, 28, 375-382

49. Kim SM, Kim DY, Park HR, Seo JH, Yeom BM, Jin YJ, Pyo YH (2014) Screening the antioxidant components and antioxidant activity of extracts derived from five varieties of edible spring flowers. Korean J Food Sci Technol, 46, 13-18

50. Nakamura M, Ra JH, Kim JS (2019) Evaluation of biological activity for Dangyuja (Citrus grandis) leaves and investigation of optimal concentrations extracted by alternative ethanol concentrations. J Plant Biotechnol, 46, 45-55

51. Takahashi M, Higuchi S (2007) Search for functional polyphenols from local plants. Rep Saitama Ind Technol Cen, 5, 81-85

52. Moon GS, Ryu BM, Lee MJ (2003) Components and antioxidative activities of Buchu (Chinese chives) harvested at different times. Korean J Food Sci Technol, 35, 493-498

53. Lee JH, Lee SR (1994) Some physiological activity of phenolic substances in plant foods. Korean J Food Sci Technol, 26, 317-323

54. Lidija J, Marihan S, Martina MK, Ivana N (2007) Anthocyanin content and antioxidant activity of various red fruit juices. DLR, 103, 58-64

55. Hong JK (2009) A Study on skin aging caused by free-radical and on efficacy of antioxidant vitamins. Kor J Aesthet Cosmetol, 7, 51-62

56. Bell DS (2004) Type 2 diabets melitus: what is the optimal treatment regimen. Am J Med, 116, 23-29

57. Lee RH, Yang SJ, Hwang TY, Chung SK, Hong JH (2015) a-Glucosidase inhibitory activity and protease characteristics produced by Bacillus amyloliquefaciens. Korean J Food Preserv, 22, 727-734

58. Jung LS, Yoon WB, Park SJ, Park DS, Ahn JH (2012) Evaluation of physicochemical properties and biological activities of steamed and fermented Deodeok (Codonopsis lanceolata). Korean J Food Sci Technol, 44, 135-139

59. Kim JW, Kim JK, Song IS, Kwon ES, Youn KS (2013) Comparison of antioxidant and physiological properties of Jerusalem artichoke leaves with different extraction processes. J Korean Soc Food Sci Nutr, 42, 68-75

60. Mohamed EA, Siddiqui MJ, Ang LF, Sadikun A, Chan SH, Tan SC, Asmawi MZ, Yam MF (2012) Potent a -glucosidase and a-amylase inhibitory activities of standardized 50\% ethanolic extracts and sinensetin from Orthosiphon stamineus Benth as anti-diabetic mechanism. BMC Complementtary Altern Med, 12, 176-182

61. Ardan T, Kovaceva J, Cejková J (2004) Comparative histochemical and immunohistochemical study on xanthine oxidoreductase/xanthine oxidase in mammalian corneal epithelium. Acta Histochem, 106, 69-75

62. Hong TG, Lee YR, Yim MH, Choung NH (2004) Physiological functionality and nitrite scavenging ability 
of fermentation extracts from pine needles. Korean J Food Preserv, 11, 94-99

63. Lee EH, Lee SH, Cho YJ (2015) Biological activities of extracts from Cornus kousa Fruit. J Appl Biol Chem, 58, 317-323

64. Shin YJ, Hwang JM, Lee SC (2013) Antioxidant and xanthine oxidase Inhibitory activities of hot water extracts of medicinal herbs. J Korean Soc Food Sci Nutr, 42, $1712-1716$
65. Kwon YR, Lee HR, Hwang SH, Kwon OJ, Youn KS (2016) Antioxidant activities and physiological properties of Euphorbia humifusa extracts prepared using different solvents. Korean J Food Preserv, 23, 252-258 